\title{
Productive, Structural and Dynamic Study of the Concept of Sustainability in the Educational Field
}

\author{
Antonio-Manuel Rodríguez-García ${ }^{1}{ }^{1}$, Jesús López Belmonte ${ }^{2}{ }^{(\mathbb{C}}$, Miriam Agreda Montoro ${ }^{3}[$ \\ and Antonio-José Moreno-Guerrero ${ }^{1, *}$ (D) \\ 1 Department of Didactics and School Organization, University of Granada, 18071 Granada, Spain; \\ arodrigu@ugr.es \\ 2 Department of Education, International University of Valencia, 46002 Valencia, Spain; \\ jesus.lopezb@campusviu.es \\ 3 Department of Pedagogy, University of Jaen, 23071 Jaen, Spain; magreda@ujaen.es \\ * Correspondence: ajmoreno@ugr.es
}

Received: 13 September 2019; Accepted: 8 October 2019; Published: 12 October 2019

\begin{abstract}
Sustainable education is currently booming in the teaching and learning processes, although it is not without complexity, due to its various dimensions and the evolution it has undergone to date. The objective of this research is to establish a mapping and scientific evolution of the term "sustainability" in education in the Web of Science database. To do so, a bibliometrical method has been applied, through the analysis of the performance of the scientific production and the evolution of the structure and dynamism of sustainability in education, by means of an analysis of co-words. The total number of references analyzed, after following a debugging process, was 9441 . The results show the boom of sustainability in education in recent times, with a great impact on research related to attitudes and sustainability. It can be concluded that a large part of the studies analyzed are of a descriptive nature, with a decrease in the number of exploratory studies, which can give a holistic vision to the subject matter presented, especially regarding the development of the curriculum and the teaching-learning process.
\end{abstract}

Keywords: scientific quantification; bibliometric techniques; literary expansion; educational sustainability; education; sustainability

\section{Introduction}

Over the last few years we have experienced a notable increase in discussions about sustainability, making it an exponentially growing research topic [1,2]. The political realities of a pluralistic and democratic society, such as the one in which we are mostly placed [3], must balance the needs of multiple groups, as well as integrate science with other sources of knowledge to provide contextualized responses to the challenges pursued to achieve true sustainable development.

The debate for sustainability aims to generate discussion and reflection about the anthropogenic challenges caused by human action, such as climate change, war, desertification, pandemics and poverty, as well as any other problem with different degrees of complexity, high repercussion and difficult or slow solution [4].

In general, education for sustainability can be defined from two different perspectives [5]: Firstly, as a threefold approach to education based on educational-related issues about, in and for the environment; and secondly, as an approach to education that includes three interrelated dimensions: The economic, the social and the environmental. More specifically, according to the UNESCO report [6], education for sustainability is composed of five dimensions and six key principles: (a) Educational (personal development); (b) political (democracy and participation); (c) social (equity and peace); (d) economic 
(meeting needs); and (e) environmental (quality environment). However, until less than a decade ago, the precision of its conceptualization was diffuse, existing contradictory debates and from multiple scopes. Over time, it was understood that the political or economic development is not dissociable from the social development and that a sustainable development is not possible if this is not extensible to the thought of the whole human community [7].

For this reason, different international organizations intend to promote education as the basis of a more viable society for humanity, as well as to integrate sustainable development at all levels of education $[6,8]$. In order to do this, it is necessary to observe and understand the environmental and developmental problems, taking into account the globalism of their aspects, as well as the repercussions they will generate in the short, medium and long term at the micro (collectivity or group of people), meso (humanity) and macro (planet) levels. Furthermore, it is necessary to understand that sustainability is not possible if the success of some implies the failure of others. Therefore, it would be necessary to replace competitiveness and the sense of individuality with cooperation and collectivity.

Despite its recognized global importance, a study [9] in which the authors analyzed more than two hundred articles dealing with the subject, shows that most of the research carried out so far is not empirical, but focuses on providing a series of orientations and guidelines to teach and learn the implications of sustainable development, rather than exploring the complexity of policy making or enactment. This finding is reaffirmed by recent research [10], which mentions that more research is needed to understand best practices and processes through which policies favoring sustainable development can be promoted.

Nevertheless, education is a powerful tool to instruct students in sustainable development [3,11], especially in university education [12]. Therefore, the scientific community seems to agree on the need to place greater emphasis on the development and promulgation of educational policies on sustainability and climate change in education [9], as well as the development of key competencies in sustainability [4]. Similarly, the findings of the other investigation [10] demonstrate the need for future research to focus on various aspects of the process of formulating and enacting policies that promote sustainability, as well as on the consequences of such policies in practice.

Traditional environmental sustainability efforts have been flawed due to their ineffectiveness [13,14]. Therefore, in their review work, the authors conclude that there is a need for a systematic management system to address environmental issues and to pay special attention to the rational use of resources in the centers. Likewise, they highlight the important work and social responsibility of the institution, as well as the need to continue carrying out educational activities related to sustainability. Other researchers [3] report the need to modernize the sustainability management system, seeing it as a set of global problems that affect all human beings equally and that can be solved by applying science and technology.

As for the work on sustainability in the educational field, one study [1], in which the authors surveyed more than a hundred instructors of management and sustainability, shows that the most used teaching resources for this type of training activity are documents, cases and videos and-to a lesser extent-electronic resources such as databases, simulations or applications [15]. On the other hand, another study [16] shows that working on sustainability in class in a punctual and transversal way in any subject is more effective than attending specific courses. Other authors [14] add that pedagogical practices should serve to foster students' capacity for critical and reflective thinking. At the same time, it is recommended to take advantage of the potential of social networks or other digital resources that students consider motivating for the work of sustainability, as they tend to give better results [15].

There can be no doubt that all organizations have an inherent responsibility to make societies more sustainable [17].

The value of this article lies in providing a vision of the scientific evolution of the concept of "sustainability" in the field of education. Hereby, the reader will be able to obtain a specific vision of the most relevant points of interest and their temporal evolution up to the present time. 


\section{Research Objectives}

Due to the importance that sustainability is acquiring in the educational field and with the intention of offering the research community a detailed perception of scientific production, as well as past, present and future trends on the subject, this study is presented with the general objective of establishing a mapping and the scientific evolution of the term "sustainability" in education, within the Web of Science (WoS) database. This objective is structured in the following specific objectives:

- To identify the scientific output and production of the terms "sustainability" and "education" in scientific texts.

- To know the scientific evolution of the concepts of sustainability and education.

- To determine the most relevant themes in the field of study on sustainability and education.

\section{Materials and Methods}

In order to develop the present study and achieve the formulated objectives, a research methodology of bibliometric nature has been used, starting from the base of previous studies reported from the scientific literature [18-20]. The use of this research technique lies in the potential reflected by scientometrics, allusive to the quantification, evaluation and estimation of scientific development in a specific field of knowledge [21].

This paper examines, on the one hand, the performance of scientific production [22] and, on the other hand, the evolution of the structure and dynamism of the concept of sustainability in education, through an analysis of co-words [23]. In order to do this, the index-h has been taken into account, as well as the citation volume [24], giving rise to the elaboration of a science map that allows observing the yield and - therefore-locating and settling the terminological subdomains of such fields of study, as well as representing the evolution of the subject in the specialized literature [25].

The database on which this study has been focused on is the Web of Science by Thomson Reuters, taking its main categorical amalgam with the purpose of agglutinating all the scientific production of impact: Science Citation Index; Social Science Citation Index; Arts and Humanities Citation Index; Conference Proceedings Citation Index Sciences/Social Sciences and Humanities; Book Citation Index Science/Social Sciences and Humanities; Emerging Sources Citation Index.

The research process took place in several phases. First, the key words concerning the topic to be addressed were selected. For this purpose, the information in the call for papers was analyzed, provided by the editors of the special issue entitled "Sustainability in Teacher Education" from the Sustainability Magazine of the prestigious MDPI group. After obtaining the search descriptors offered by these experts (education for sustainable development, environmental education, teacher education, teacher competencies, pre-service teacher education, in-service teacher education, teacher education curriculum and teacher education programs), the thesauri of UNESCO and ERIC were searched, reporting the terms "sustainability" and "education" in order to complement the search range.

To specify the search action, the Boolean operator "sustainability" and "education" was defined and applied in the title, abstract and keywords filters of all the works collected in WOS, assuming the possible margin of error that can generate the use of generic concepts, such as "sustainability", which acquires different perspectives depending on the context in which it is located or the discipline from which it comes. The period for locating and downloading documents began in May 2019 and lasted for three months. A total of 9490 references were reported, of which, after a process of analysis and refinement-deleting documents not related to the search equation-a figure of 9441 scientific works, allusive to the field of study in question, is finally recorded.

The tool used for performance analysis is the WoS Analyze Results and Creation Citation Report, identifying the year, type of document, institution, author, journal, country and language of greatest production, as well as the most cited document in the three established educational stages. For structural and dynamic development, SciMAT software has been used, efficiently favoring all the statistical deployment necessary to meet the objectives established in this study. 
The analysis of longitudinal co-words has been structured in four distinct moments, following the recommendations of experts in these types of studies [26]:

Recognition of the topics: For this purpose, the keywords $(n=22,841)$ of the downloaded documents were analyzed, generating a co-occurrence network through nodes, originating a normalized structure of co-words and reaching the keywords with greater relevance $(n=21,979)$ by means of a clustering algorithm that reports the topics of study and, consequently, finds the terms that acquire greater connection.

Reproduction of the topics: It was carried out by means of a strategic diagram and a thematic network [27] integrated by the centrality dimension and the relative density. This gave rise to the representation of the themes in four sectors (top left = low connectivity with nodes of little relevance; top right $=$ high connectivity and thematic relevance; bottom left = emerging or disappearing themes; bottom right $=$ basic and transversal).

Determination of thematic focuses: Obtained through the analysis of the temporal development reflected in the nodes in different periods of time. The strength of association is reached according to the number of common keywords. In this research three periods have been configured ( $\mathrm{P} 1=2009-2012$; P2 = 2013-2015; P3 = 2016-2019), trying to maintain equitable periods as far as the number of productions is concerned.

Performance caused: The keywords reported contain inside a network of links with other terms that establish the position of the node. In order to analyze its productivity, a series of criteria have been defined (Table 1).

Table 1. Configuring performance analysis.

\begin{tabular}{cc}
\hline Configuration & Values \\
\hline Analysis unit & Keywords \\
Frequency reduction & $\mathrm{P} 1(7), \mathrm{P} 2(11), \mathrm{P} 3(14)$ \\
Kind of matrix & Co-occurrence \\
Network reduction & P1(4), P2(4), P3(9) \\
Normalization measure & Equivalence index \\
Clustering algorithm & Maximum: 9, minimum: 3 \\
Evolution map & Jaccard Index \\
Overlapping map & Inclusion index \\
\hline
\end{tabular}

\section{Results}

The results obtained in the analysis carried out are presented below, showing, on the one hand, the most relevant data on scientific output and production and, on the other hand, the structural and thematic development of the established field of knowledge.

\subsection{Performance and Scientific Production}

The scientific production on the established theme begins in 2009, growing steadily until 2018, which is where the largest production is collected, with a total of 1573 documents. In the month of August, the production of 2019 amounts to 850. The scientific community mainly makes use of the articles to show the results achieved, this type of document representing $73.33 \%$ of the total. The University of California System is the organization, with a total of $1.46 \%$, that has more done research on the subject. Among the authors, Walter Leal Filho is the one that accumulates the greatest scientific production, with a total of 28 documents. The main journal that publishes on the subject studied is Sustainability, with a total of 447 documents. The United States has the highest level of creation, with a total of 2436 scientific productions, $25.65 \%$ of the total. Finally, the language used by the scientific community is English, with $94 \%$ of the total registered production. 


\subsection{Structural and Thematic Development}

The continuity of keywords between the established periods-P1(2009-2012), P2(2013-2015) and P3(2016-2019)—shows how the field of knowledge is settling down in recent times. The first period, with 5419 keywords, evolves to the second period with 7642 keywords, disappearing 3565 and incorporating 5788. Between both periods, the coincidence of keywords is $34 \%$. The evolution of the second period shows a more consolidated connection, with $41 \%$ of keyword matches. From the second period the existence of 4535 keywords is verified and 11,495 are incorporated. The total number of keywords in the last period is 14,602 . It is shown how the volume of words evolves between the established periods, this evolution ascending, giving a glimpse of the interest on the part of the scientific community in the established field of knowledge (Figure 1).

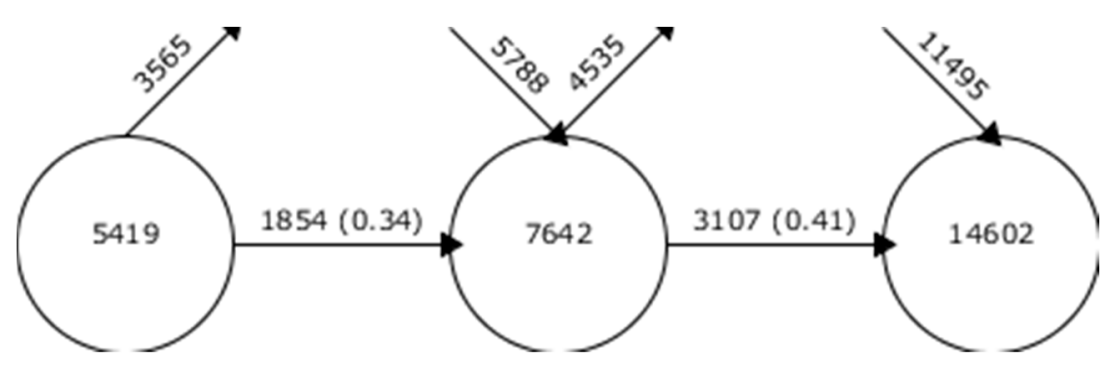

Figure 1. Continuity of keywords between contiguous periods.

The bibliometric indicators of the three periods, displayed in Table 2, show that between 2009 and 2012 , the themes with the highest values are sustainability and sustainability-development. Between 2013 and 2015 the themes change, with university and education aving the highest bibliometric values. In the last period, between 2016 and 2019, sustainability is once again the theme with the highest indexes, followed at a considerable distance by performance.

Analyzing the strategic diagram of the first period, between 2009 and 2012, the sustainability themes are shown as motor themes, which focus on higher education, administration, curriculum, university, plans, environment, education and multidiscipline; and also intervention, in which research is oriented towards precaution, psychic activity, disease, projects and prevention. The sustainable development theme, although it is situated as a basic and transversal theme, shows a high $\mathrm{H}$ index, being relevant for the scientific community. In this case, the theme is related to education in engineering, curriculum, learning, skills, difficulties, science, students and education for sustainability. In this period, policy, which focuses on behavior and implementation, is placed as an unknown subject, as reflected in Figure 2. 
Table 2. Thematic performance by period.

\begin{tabular}{|c|c|c|c|c|c|c|}
\hline \multicolumn{7}{|c|}{ Period 2009-2012 } \\
\hline Name & Works & Index-h & Index-g & Index-hg & Index-q2 & Citations \\
\hline Sustainability & 230 & 33 & 58 & 43.75 & 45.23 & 4472 \\
\hline Sustainable-development & 45 & 21 & 33 & 26.32 & 25.51 & 115 \\
\hline Intervention & 17 & 11 & 17 & 13.67 & 18.17 & 467 \\
\hline Knowledge & 21 & 11 & 20 & 14.83 & 18.17 & 478 \\
\hline Biodiversity & 8 & 6 & 7 & 6.48 & 13.42 & 216 \\
\hline Performance & 8 & 5 & 7 & 5.92 & 12.65 & 213 \\
\hline Policy & 8 & 7 & 8 & 7.48 & 10.91 & 174 \\
\hline \multicolumn{7}{|c|}{ Period 2013-2015 } \\
\hline Name & Works & Index-h & Index-g & Index-hg & Index-q2 & Citations \\
\hline University & 197 & 28 & 47 & 36.28 & 39.24 & 3151 \\
\hline Health & 56 & 15 & 23 & 18.57 & 20.12 & 738 \\
\hline Education & 175 & 24 & 35 & 28.98 & 29.39 & 1995 \\
\hline Management & 50 & 16 & 27 & 20.78 & 21.91 & 797 \\
\hline Attitudes & 44 & 17 & 24 & 20.2 & 18.44 & 712 \\
\hline Students & 39 & 11 & 15 & 12.85 & 13.67 & 308 \\
\hline Model & 22 & 8 & 18 & 12 & 12.33 & 325 \\
\hline Environmental-education & 13 & 5 & 9 & 6.71 & 8.94 & 88 \\
\hline Sustainability-education & 11 & 6 & 10 & 7.75 & 10.39 & 115 \\
\hline Tool & 8 & 5 & 7 & 5.92 & 13.42 & 147 \\
\hline Quality of life & 7 & 5 & 7 & 5.92 & 7.75 & 178 \\
\hline Implementation & 9 & 8 & 9 & 8.49 & 13.56 & 289 \\
\hline \multicolumn{7}{|c|}{ Period 2016-2019 } \\
\hline Name & Works & Index-h & Index-g & Index-hg & Index-q2 & Citations \\
\hline Sustainability & 1168 & 20 & 25 & 22.36 & 21.45 & 2948 \\
\hline Intervention & 125 & 8 & 11 & 9.38 & 9.8 & 329 \\
\hline Education for sustainability & 82 & 8 & 10 & 8.94 & 10.58 & 214 \\
\hline Attitudes & 110 & 10 & 14 & 11.83 & 13.42 & 375 \\
\hline Performance & 172 & 13 & 21 & 16.52 & 16.91 & 640 \\
\hline Sustainable-development & 98 & 10 & 14 & 11.83 & 13.04 & 322 \\
\hline Ethics & 27 & 5 & 6 & 5.48 & 5.92 & 51 \\
\hline Conservation & 24 & 5 & 13 & 8.06 & 8.37 & 177 \\
\hline Policy & 22 & 6 & 11 & 8.12 & 10.39 & 128 \\
\hline
\end{tabular}

In the strategic diagram of the second period, between 2013 and 2015, more issues arise than in the first period. As driving themes are the university themes, which are the most relevant in this period. They relate to sustainable campus, responsibilities of social corporations, curriculum, organizational changes, education for sustainability, sustainability, key competencies and higher education; health, which is associated with psychic activity, obesity, nurses, impact, intervention, programs, adolescents and health promotion; education, which refers to curriculum, learning, research, attitude, politics, science and sustainable development; and management, which deals with leadership, water, urban, systems, perceptions, environment, organizations and resilience. In this period, the attitudes theme stands out, which is situated between the motor and basic or transversal theme, in addition to implementation, which is related to environmental management and quality; environmental education, which is associated with teacher education and neoliberalism; and sustainability education, which is conspired with pedagogy, future and context, all of them located as unknown themes, shown in Figure 3. 


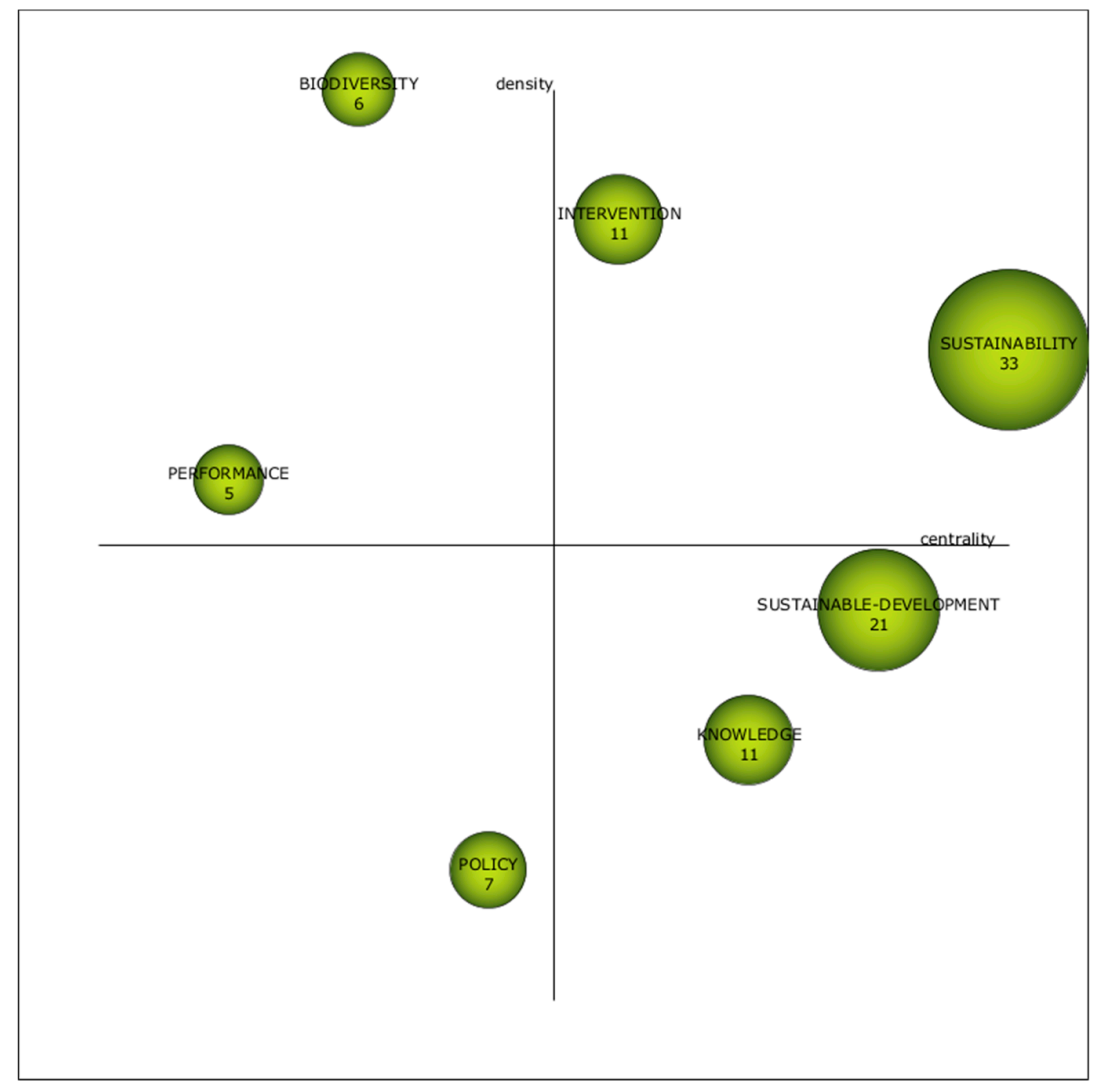

Figure 2. Strategic h-index diagram for the period 2009-2012.

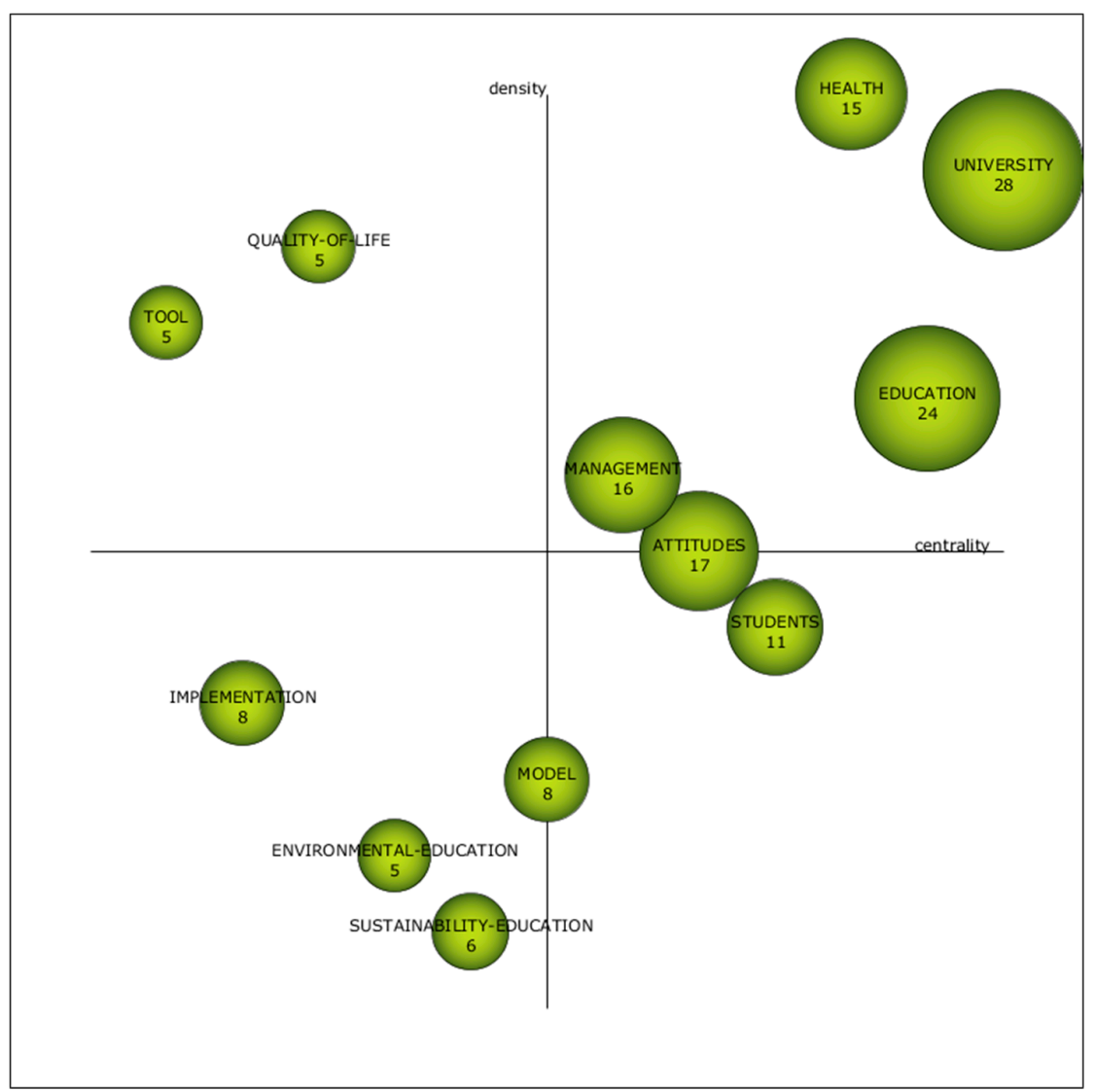

Figure 3. Strategic h-index diagram for the period 2013-2015. 
In the last period established—between 2016 and 2019—sustainability motor themes are shown as the most relevant by position and bibliometric indicators. These are related to higher education, management, environmental education, university, science, education, climate change and knowledge; and attitudes, which are associated with intentions, pro-environmental behavior, gender, perceptions, determining factors, attitudes, values and students. In this period the performance theme is noteworthy. Although it is situated as a basic and transversal theme, it continues to be of interest to the scientific community, given its high bibliometric indicators, making reference to innovation, energy, cooperative social responsibility, impact, systems, models, strategies and context. In addition, policy is worth noticing, because it is an unknown topic, as its situation in the diagram shows. It must be taken into account because it may be a driving theme in the future. Research is geared towards governments and difficulties, as shown in Figure 4.

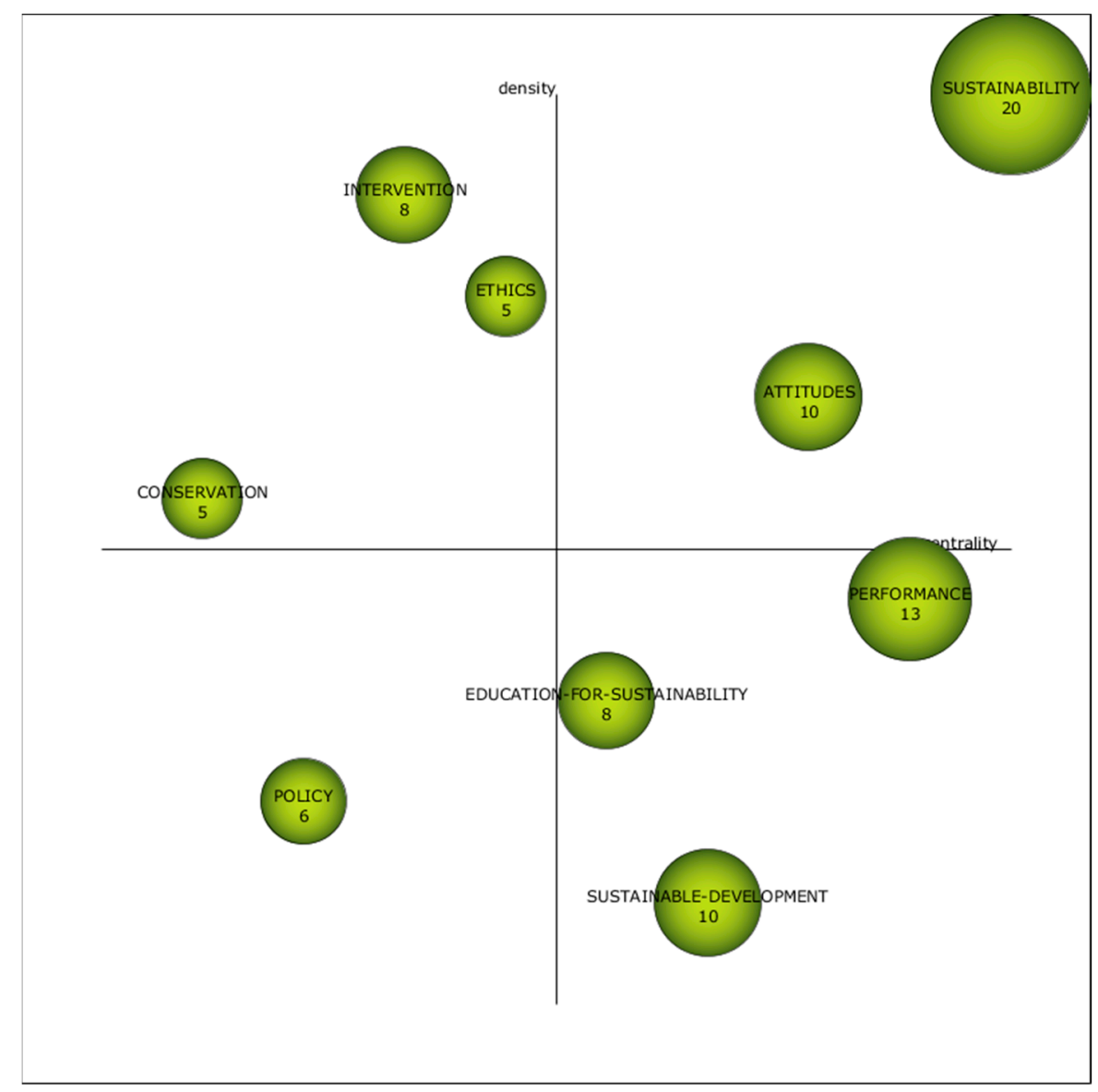

Figure 4. Strategic h-index diagram for the period 2006-2019.

Focusing the analysis on the thematic evolution in the field of knowledge, it should be borne in mind that the connections established by means of a continuous line show a conceptual relationship, given that their connection is thematic, while the discontinuous line offers a non-conceptual relationship, since their union is through key words.

The first thing that can be interpreted from Figure 5 is the appearance of conceptual gaps between periods, since there is no theme that is repeated in the three phases. There are themes which appear in the first and third periods, such as sustainability, sustainability-development, intervention, performance and policy. This shows a change of trend between the first and second periods on the part of the scientific community, returning in the third period to the basis of studies of the first stage established. The second period shows conceptual evolution in the subject attitudes, which reflects the new interest of the scientific community in this topic. 


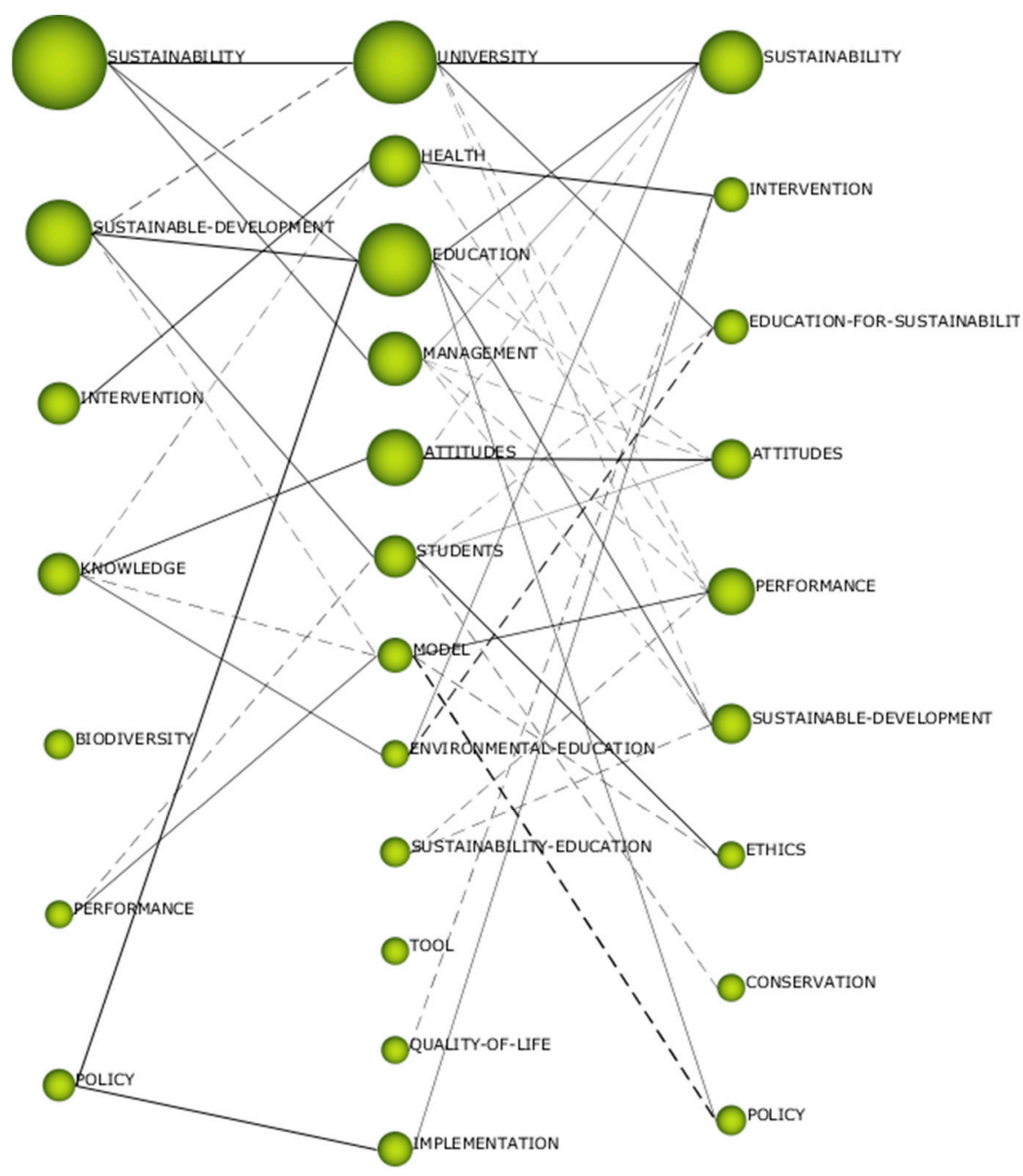

Figure 5. Thematic evolution by index-h.

The relations established between the second and third periods are more abundant than those established between the first and second periods. Between the first and second periods, it stands out the conceptual relationships of sustainability with university, education and management; sustainable-development with education and students; intervention with health; knowledge with attitudes and environmental-education; performance with model; and policy with education and implementation.

Between the second and third periods, it is brought into focus the conceptual connections marked by university with sustainability and education for sustainability; health with intervention; education with sustainability, sustainable-development and policy; management with sustainability; attitudes with oneself; students with attitudes and ethics; model with performance; environmental-education with sustainability; and implementation with intervention.

\section{Discussion}

The progressive increase in publications related to sustainability in the educational field in recent years, especially since 2013, explains the notability it has acquired in this field of study, in practice and in the academic world. According to the results, it is observed that in a first period the descriptors associated with sustainable education have been closely linked to the disciplines that make up the sciences. However, the evolution of the scientific literature confirms that sustainability and sustainable development not only encompass a purely environmental dimension, but also have to take into account 
social, economic and institutional contexts [28], the latter being of great importance due to the formative roles assumed in the institutions [14,29].

In this way, the research carried out has evolved towards a transdisciplinary vision that attempts to explain the emerging theme from pedagogical approaches focused on the professional development of teachers on the formation of a sustainable citizenship from early ages, to higher studies [30,31], technology-mediated learning for a sustainable education [32,33], as well as the imminent need for teacher training to integrate skills related to education for sustainability, considering both individual differences and the common good of the community [34].

Referring to the second period, which includes the inclusion of disciplines in fields such as health and psychology in conjunction with education, other experts [35] in a bibliometric study concluded by establishing a connection between socio-cultural factors and the goals of sustainable development as determinants in the mental disorders of individuals, indicating the importance of individual social capital, social participation, social support and education.

Finally, the need for a real integration in the educational policies of a sustainable education for teacher training and real teaching activities [9] is highlighted. Nevertheless, educational policies must be materialized in the initial teacher training, since the emphasis placed on the attitudes and training of students is reflected in the last analysis period, as well as in the management and educational policies for sustainability, but with certain lacks in studies that focus on teacher training, curriculum implementation and skills acquisition [36-39].

\section{Conclusions}

The diversity of articles analyzed for this work is an indicator of the progress and relevance of sustainability in today's society in which the individual operates. The academic and scientific world has progressed and tried to respond to international demands derived, above all, from the inclusion by UNESCO of Education for Sustainable Development as an area of action, and it also points to the strength of the education to achieve the proposed objectives [40].

Nonetheless, it has been observed that the vast majority of studies have been descriptive, having reduced the number of exploratory studies that could give a holistic view of the subject, especially in regard to the development of the curriculum and the teaching-learning process, and not only in the field of higher education, but at compulsory educational levels. Similarly, several stages have been found in which the majority term has been "sustainable-development", that is, a direct approach to scientific literature referring to climate, the improvement of the environment or business, among others. However, in recent years there has been a change in the tendency to carry out research in which the focus is on education, closely related to the progress of society.

Finally, the systematic review carried out strengthens the gradual recognition of education as a key element in achieving the goals of developing a citizenship educated in sustainability, from different international organizations such as the UN and UNESCO. This situation has been evidenced by the increase in scientific literature, taking into account the inclusion of the subject in publications that, a priori, focused on other fields of study, as well as researchers who decide to study phenomena or events concerning education sustainability. Therefore, we face an emerging transdisciplinary field with great potential to produce an impact on policies and practices in all the systems that make up society.

Author Contributions: Conceptualization, A.-M.R.-G., M.A.M. and J.L.B.; methodology, J.L.B.; software, A.-J.M.-G.; formal analysis, A.-J.M.-G.; investigation, A.-J.M.-G., A.-M.R.-G., M.A.M. and J.L.B.; data curation, A.-J.M.-G.; writing-original draft preparation, A.-M.R.-G., M.A.M. and J.L.B.; writing-review and editing, A.-M.R.-G. and M.A.M.; visualization, A.-J.M.-G., A.-M.R.-G., M.A.M. and J.L.B.; supervision, A.-J.M.-G., A.-M.R.-G., M.A.M. and J.L.B.

Funding: This research received no external funding.

Conflicts of Interest: The authors declare no conflict of interest. 


\section{References}

1. Aragon-Correa, J.A.; Marcus, A.A.; Rivera, J.E.; Kenworthy, A.L. Sustainability Management Teaching Resources and the Challenge of Balancing Planet, People, and Profits. AMLE 2017, 16, 469-483. [CrossRef]

2. Bessant, S.E.F.; Robinson, Z.P.; Ormerod, R.M. Neoliberalism, new public management and the sustainable development agenda of higher education: History, contradictions and synergies. Environ. Educ. Res. 2015, 21, 417-432. [CrossRef]

3. Feinstein, N.W.; Kirchgasler, K.L. Sustainability in Science Education? How the Next Generation Science Standards Approach Sustainability, and Why It Matters. Sci. Educ. 2015, 99, 121-144. [CrossRef]

4. Wiek, A.; Withycombe, L.; Redman, C.L. Key competencies in sustainability: A reference framework for academic program development. Sustain. Sci. 2011, 6, 203-218. [CrossRef]

5. Hedefalk, M.; Almqvist, J.; Ostman, L. Education for sustainable development in early childhood education: A review of the research literature. Environ. Educ. Res. 2015, 21, 975-990. [CrossRef]

6. UNESCO. National Journeys, towards Education for Sustainable Development, United Nations Decade of Education for Sustainable Development 2005-2014; UNESCO: Paris, France, 2011.

7. Calixto, P.S.; Hernández, M.A. La evolucion del concepto de sostenibilidad y su incidencia en la educacion ambiental. Teoría de la Educación 2008, 20, 179-207.

8. Wals, A.E. Sustainability in higher education in the context of the UN DESD: A review of learning and institutionalization processes. J. Clean. Prod. 2014, 62, 8-15. [CrossRef]

9. Aikens, K.; McKenzie, M.; Vaughter, P. Environmental and sustainability education policy research: A systematic review of methodological and thematic trends. Environ. Educ. Res. 2016, 22, 333-359. [CrossRef]

10. Cheeseman, A.; Wright, T.S.A.; Murray, J.; McKenzie, M. Taking stock of sustainability in higher education: A review of the policy literature. Environ. Educ. Res. 2019, 1-16. [CrossRef]

11. Christie, B.A.; Miller, K.K.; Cooke, R.; White, J.G. Environmental sustainability in higher education: What do academics think? Environ. Educ. Res. 2015, 21, 655-686. [CrossRef]

12. Murray, J. Student-led action for sustainability in higher education: A literature review. Int. J. Sustain. High. Educ. 2018, 19, 1095-1110. [CrossRef]

13. Amaral, L.P.; Martins, N.; Gouveia, J.B. Quest for a sustainable university: A review. Int. J. Sustain. High. Educ. 2015, 16, 155-172. [CrossRef]

14. Howlett, C.; Ferreira, J.A.; Blomfield, J. Teaching sustainable development in higher education Building critical, reflective thinkers through an interdisciplinary approach. Int. J. Sustain. High. Educ. 2016, 17, 305-321. [CrossRef]

15. Hamid, S.; Ijab, M.T.; Sulaiman, H.; Anwar, R.M.; Norman, A.A. Social media for environmental sustainability awareness in higher education. Int. J. Sustain. High. Educ. 2017, 18, 474-491. [CrossRef]

16. Fisher, P.B.; McAdams, E. Gaps in sustainability education. The impact of higher education coursework on perceptions of sustainability. Int. J. Sustain. High. Educ. 2015, 16, 407-423. [CrossRef]

17. Findler, F.; Schoenherr, N.; Lozano, R.; Reider, D.; Martinuzzi, A. The impacts of higher education institutions on sustainable development-A review and conceptualization. Int. J. Sustain. High. Educ. 2019, 20, $23-38$. [CrossRef]

18. Hinojo-Lucena, F.J.; Aznar-Díaz, I.; Cáceres-Reche, M.P.; Romero-Rodríguez, J.M. Artificial Intelligence in Higher Education: A Bibliometric Study on its Impact in the Scientific Literature. Educ. Sci. 2019, 9, 51. [CrossRef]

19. Marín-Marín, J.A.; López-Belmonte, J.; Fernández-Campoy, J.M.; Romero-Rodríguez, J.M. Big Data in Education. A Bibliometric Review. Soc. Sci. 2019, 8, 223. [CrossRef]

20. Moreno-Guerrero, A.J. Estudio bibliométrico de la producción científica sobre la Inspección Educativa. REICE 2019, 17, 23-40. [CrossRef]

21. Martínez, M.A.; Cobo, M.J.; Herrera, M.; Herrera, E. Analyzing the scientific evolution of social work using science mapping. RSWP 2015, 25, 257-277. [CrossRef]

22. Rodríguez-García, A.M.; Trujillo, J.M.; Sánchez, J. Impact of scientific productivity on digital competence of future teachers: Bibliometric approach on Scopus and Web of Science. RCDE 2019, 30, 623-646. [CrossRef]

23. Hirsch, J.E. An index to quantify an individual's scientific research output. Proc. Natl. Acad. Sci. USA 2005, 102, 16569-16572. [CrossRef] [PubMed] 
24. Cobo, M.J.; López, A.G.; Herrera, E.; Herrera, F. Science mapping software tools: Review, analysis, and cooperative study among tools. J. Am. Soc. Inf. Sci. Technol. 2011, 62, 1382-1402. [CrossRef]

25. López-Robles, J.R.; Otegi-Olaso, J.R.; Porto-Gómez, I.; Cobo, M.J. 30 years of intelligence models in management and business: A bibliometric review. IJIM 2019, 48, 22-38. [CrossRef]

26. Cobo, M.J.; López, A.G.; Herrera, E.; Herrera, F. SciMAT: A new science mapping analysis software tool. J. Am. Soc. Inf. Sci. Technol. 2012, 63, 1609-1630. [CrossRef]

27. Moreno-Guerrero, A.J. Evolución temática de la producción científica de la revista DEDiCA. DEDiCA Rev. Educ. Humanid. 2019, 16, 189-206. [CrossRef]

28. Thürer, M.; Tomašević, I.; Stevenson, M.; Qu, T.; Huisingh, D. A systematic review of the literature on integrating sustainability into engineering curricula. J. Clean. Prod. 2018, 181, 608-617. [CrossRef]

29. Mulder, K.F.; Segalas, J.; Ferrer-Balas, D. How to educate engineers for/in sustainable development: Ten years of discussion, remaining challenges. Int. J. Sustain. High. Educ. 2012, 13, 211-218. [CrossRef]

30. Bascopé, M.; Perasso, P.; Reiss, K. Systematic Review of Education for Sustainable Development at an early stage: Cornerstones and pedagogical approacher for teacher professional development. Sustainability 2019, 11, 719. [CrossRef]

31. Singer-Brodowski, M.; Brock, A.; Etzkorn, N.; Otte, I. Monitoring of education for sustainable development in Germany-insights from early childhood education, school and higher education. Environ. Educ. Res. 2018, 1-16. [CrossRef]

32. Daniela, L.; Visvizi, A.; Gutiérrez-Braojos, C.; Lytras, M.D. Sustainable Higher Education and Technology-Enhanced Learning (TEL). Sustainability 2018, 10, 3883. [CrossRef]

33. Stanitsas, M.; Kirytopoulos, K.; Vareilles, E. Facilitating sustainability transition through serious games: A systematic literature review. J. Clean. Prod. 2018, 208, 924-936. [CrossRef]

34. Chinedu, C.C.; Wan, W.A.; Ajah, A.O. A systematic review on education for sustainable development: Enhancing TVE teacher training programme. JTET 2018, 10, 109-125. [CrossRef]

35. Lund, C.; Brooke-Sumner, C.; Baingana, F.; Baron, E.C.; Breuer, E.; Chandra, P.; Medina-Mora, M.E. Social determinants of mental disorders and the Sustainable Development Goals: A systematic review of reviews. Lancet Psychiatry 2018, 5, 357-369. [CrossRef]

36. Bürgener, L.; Barth, M. Sustainability competencies in teacher education: Making teacher education count in everyday school practice. J. Clean. Prod. 2018, 174, 821-826. [CrossRef]

37. Cebrián, G.; Junyent, M. Competencies in education for sustainable development: Exploring the student teachers' views. Sustainability 2015, 7, 2768-2786. [CrossRef]

38. Sahakian, M.; Seyfang, G. A sustainable consumption teaching review: From building competencies to transformative learning. J. Clean. Prod. 2018, 198, 231-241. [CrossRef]

39. Wu, Y.-C.J.; Shen, J.P. Higher education for sustainable development: A systematic review. Int. J. Sustain. High. Educ. 2016, 17, 633-651. [CrossRef]

40. UNESCO. Shaping the future we want: Final Report. In UN Decade of Education for Sustainable Development (2005-2014); UNESCO: Luxemburg, 2014; pp. 1-196. [CrossRef]

(C) 2019 by the authors. Licensee MDPI, Basel, Switzerland. This article is an open access article distributed under the terms and conditions of the Creative Commons Attribution (CC BY) license (http://creativecommons.org/licenses/by/4.0/). 